\title{
奈良先端科学技術大学院大学先端科学技術研究科 物質創成科学領域技術職員室の紹介
}

\author{
Technical Staff Office, Division of Materials Science, \\ Graduate School of Science and Technology, \\ Nara Institute of Science and Technology
}

西川嘉子

Yoshiko NishiKawa

奈良先端科学技術大学院大学 研究・国際部 研究協力課

\section{1. 奈良先端科学技術大学院大学先端科学技術研究科 物質創成科学領域技術職員室 概要}

奈良先端科学技術大学院大学は，1991年10月に学部を置かない新構想の国立大学院大学として創設され，1993年4月に 情報科学研究科，1994年4月にバイオサイエンス研究科，1998年4月に物質創成科学研究科とスタートさせた新しい大学 です.そして本年 2018 年 4 月に先端科学技術研究科として 3 研究科を 1 研究科 1 専攻として再スタートしました. 現在, 学生数 1,072 人, 教職員数 373 人（平成 29 年 10 月 1 日現在）の小規模な大学です.

私の所属は, 研究・国際部 研究協力課で, 形式的には事務局所属で物質創成科学領域に派遣されている技術職員です.

技術職員室は，ナノテクノロジープラットフォーム実施責任者 河合 壮教授 (物質創成科学領域副領域長兼任)，連携 担当 清水 洋特任教授, 技術専門職員 8 名, 技術支援員 4 名の計 14 名で構成されています (写真 1 )。物質創成科学研究領 域では，共通設備機器を大小含めて 74 台保有しており，技術職員室のスタッフで担当装置数台をクロスオーバーして管理 運営しています。

技術職員室には河合教授を除く 13 名が一つの居室を共有しており，問題を抱えた依頼者が技術職員室に技術相談に来 られたとき，多方面からアドバイスを行うことができます。そのため，多岐にわたり解決案を提案することができるバッ クアップ体制が整っているのは本技術職員室の利点であると感じています.

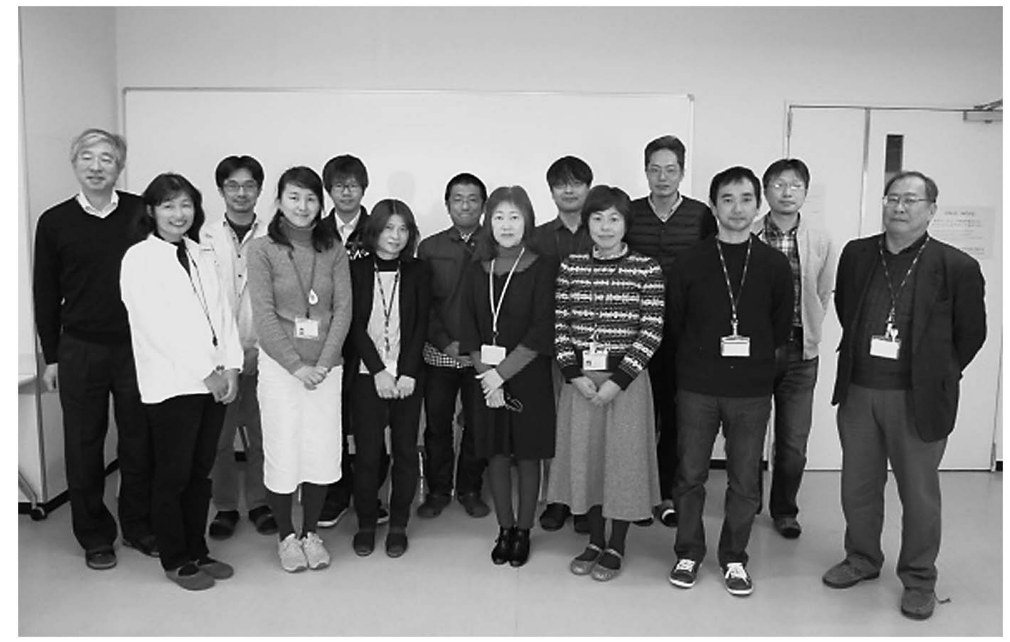

写真 1 . 先端科学技術研究科物質創成科学領域技術職員室一同（後列左 1 番目 : 河合先生, 前列右 1 番目: 清水先生, 前列右から 3 番目：西川). 


\section{2. ナノテクプラットフォーム事業について}

物質創成科学領域では平成 24 年度より 10 年間文部科学省事業，JST（科学技術振興機構）委託としてナノテクノロジー プラットフォーム事業，分子・物質合成プラットフォーム事業（http://nanonet.mext.go.jp）に参画しています。「ナノテク ノロジープラットフォーム事業」とは「ナノテクノロジーに関する最先端の研究設備とその活用のノウハウを有する機関 が緊密に連携して, 全国的な設備の共用体制を共同で構築するものです。本事業を通じて，産学官の多様な利用者による 設備の共同利用を促進し，産業界や研究現場が有する技術的課題の解決へのアプローチを提供すると共に，産学官連携や 異分野融合を推進します.」とされています.

この事業により，学外から（大学，企業を含め）の依頼測定を行っています．質量分析に関しては，全体の $23 \%$ 程度が ナノテクプラットフォーム事業関連依頼となっています。このおかげで学内だけでは扱わない多様なサンプルを測定でき るため，楽しく仕事をしています。

\section{3. 質量分析との出会い}

私はもともと, 大学卒業後, 岡山大学工学部生物機能工学科に技官として就職しました。就職してこれから技術的な仕 事ができると意気揚々と岡山に向かったものの9割くらいは研究室の会計管理で, 残り1割で学生実習のお手伝いという 仕事でした。（とは言え，このおかげで大学の予算の仕組みを勉強できました.）

そこで, 異動願いを出していたのですが運よく奈良先端科学技術大学院大学物質創成科学研究科（当時）にて質量分析 担当技官が 1 年足らずで急遽退職されて困っていたという状況の当時共通機器を管理されていた垣内喜代三教授（現 副 学長）が「打たれ強そう！！」という理由で気に入っていただき，幸いにも異動してくることができました。今思えば，人 生最大の運をここで使ったのでは？と思います.

私はもともと, 大学時代化学を専攻していましたが, 質量分析は授業で習った程度のほとんど知らないレべルであった ため, 奈良先端大に来て初めて本格的に勉強を始めました。当時, 本研究領域にあった質量分析計は日本電子製JMS-700 (写真2)とApplied Biosystems製Voyager DE-STR（写真3）の2台でした. Voyagerは学生さんに開放にしており，自由に 使っていただいていたので, JMS-700のみ扱い始めました。最初の講習は当時の垣内研の学生さんでいきなり何の説明も なく分解能 10,000 固定で, 測定したい質量の土50 Daの範囲で精密質量を測るといった手法で，その学生さん曰く「合う ときは合うし，合わないときは合わないんですよね（計算精密質量と測定精密質量が近くなる）」とのこと．30分程度教え ていただいて「後はよろしく」と言われました。とは言え，垣内先生は前述の技官さんが突然辞めてしまわれたので，今 回は大切に报おうといろいろお気遣いいただき，異動して半年は質量分析の勉強に専念させていただきました。その甲斐 あって，何とか通常のマススペクトルの測定から精密質量測定まで一通り勉強でき，電子イオン化（electron ionization; EI）法，高速原子衝撃（fast atom bombardment; FAB）法を測定できるようになりました。しかし，かなりの手探り状態 で，しかもたくさんのトラブルにも遭い，そのたびにJMS-700に「何が不満やねんっっ！！」と怒りながらたくさんの苦 難を乗り越えてきました。その間，質量分析学会を通してたくさんの先生方と，他大学の技術職員の方々に出会えたおか げで人脈が増え，相談できる人たちが増えたのは私の最大の財産です.

\section{4. 現在の質量分析装置}

異動当初，2台しかなかった質量分析計が現在は5台にまで増えました。JEOL JMS-700 \{EI, FAB, 化学イオン化（chemi-

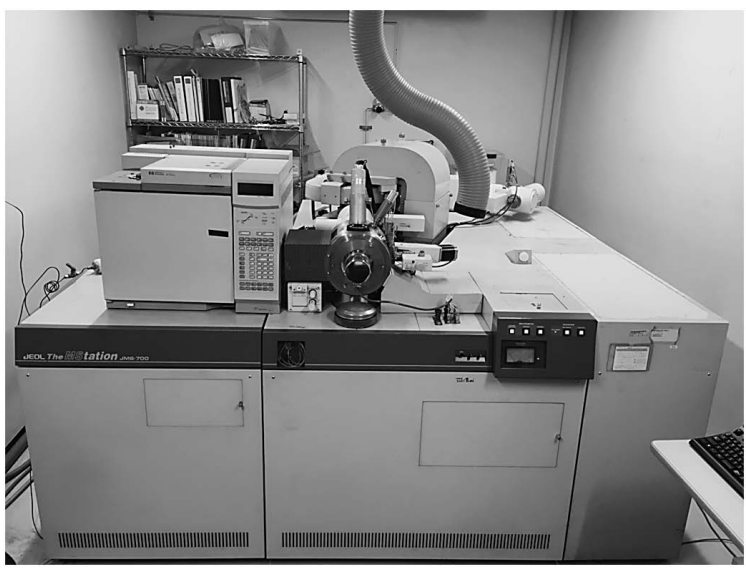

写真2. JEOL JMS-700 MStation二重収束質量分析計.

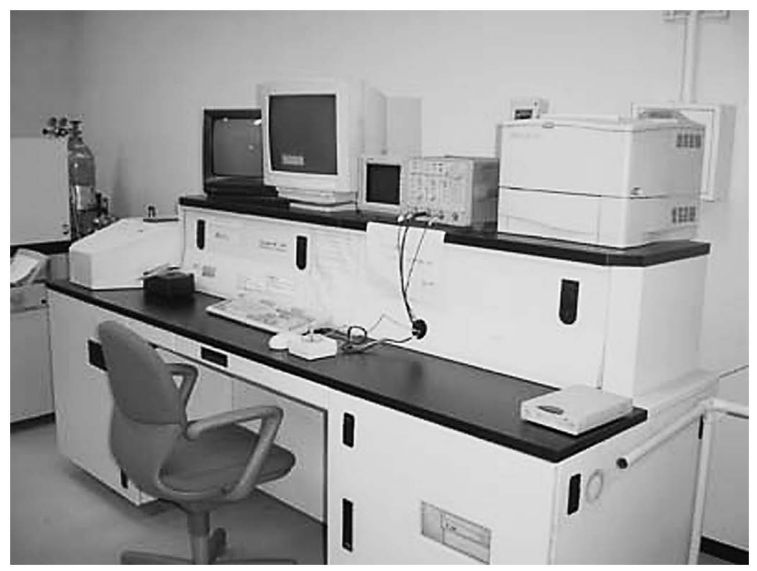

写真3. Applied Biosystems Voyager DE-STR飛行時間型質量 分析計. 


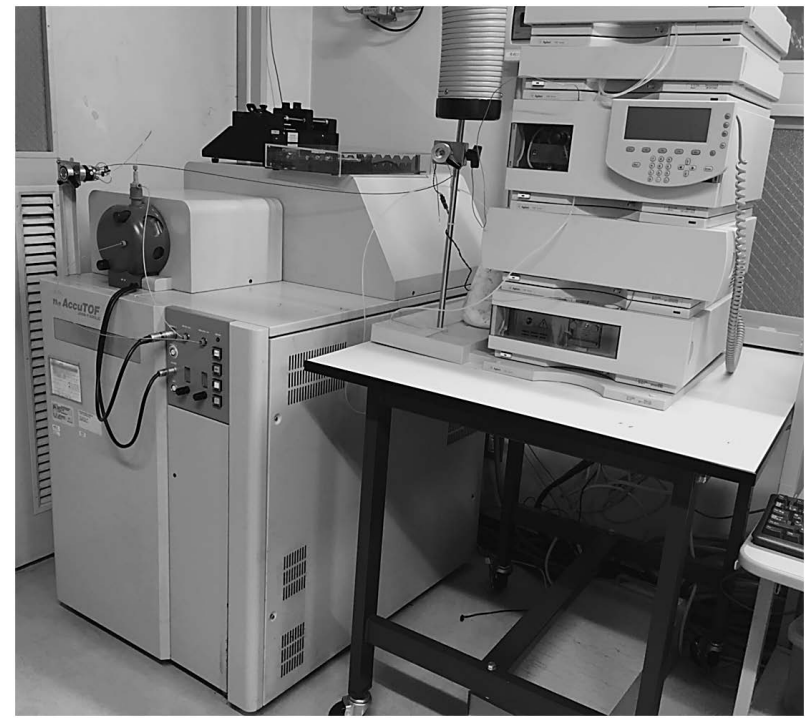

写真4. JEOL JMS-T100LC AccuTOF ${ }^{m}$ 液体クロマトグラ フィー飛行時間型質量分析計.

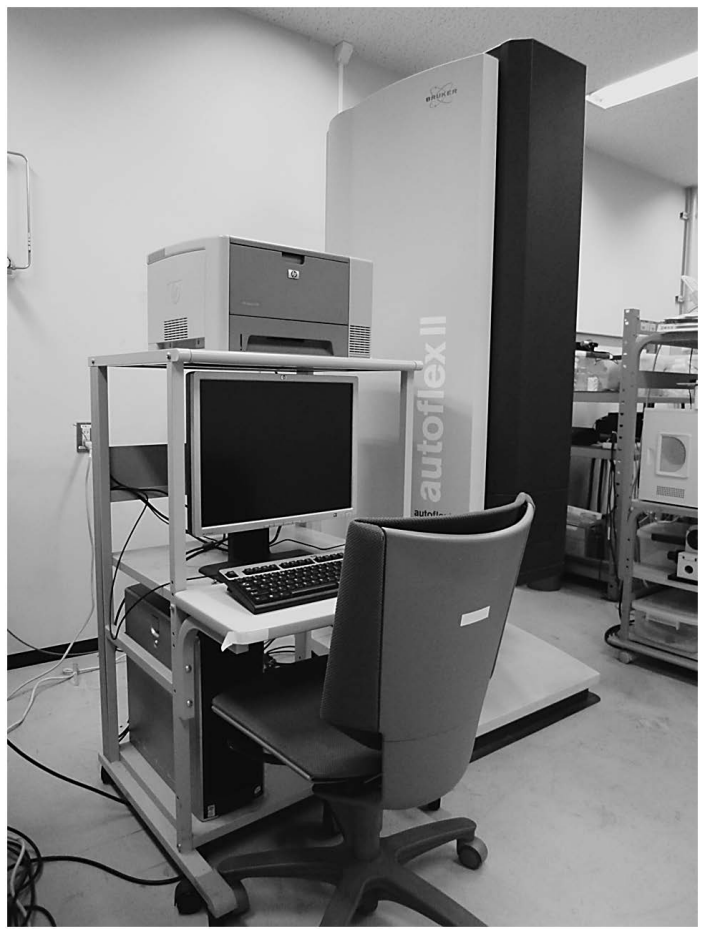

写真5. Bruker Daltonics Autoflex2マトリックス支援レー ザー脱離イオン化飛行時間質量分析計.

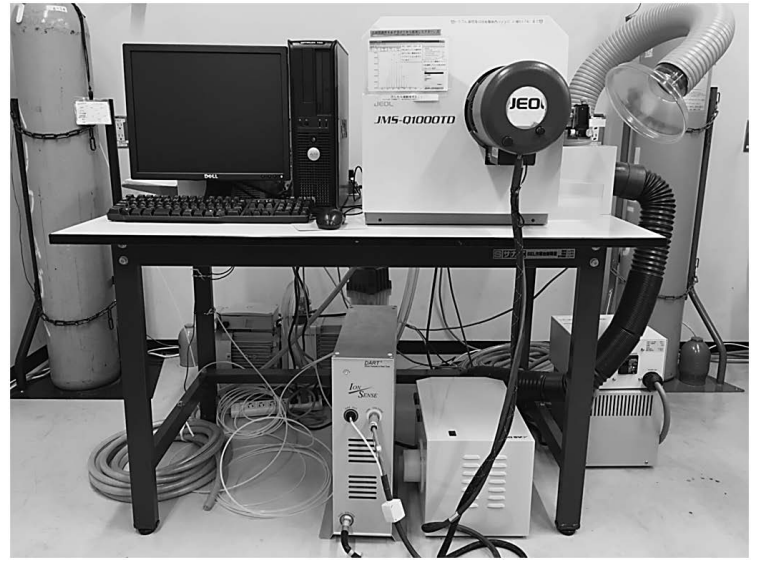

写真6. JEOL JMS-Q1000TD薄層クロマトグラフィー質量分 析計.

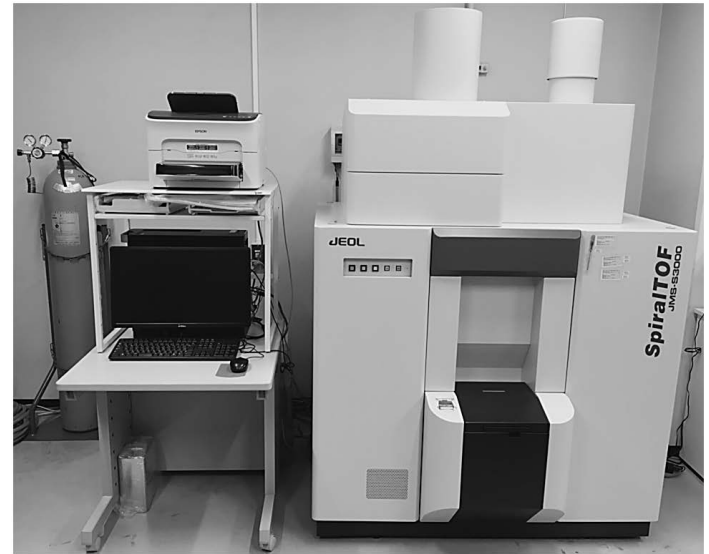

写真7. JEOL JMS-S3000マトリックス支援レーザー脱離イ オン化飛行時間型質量分析計.

cal ionization; CI) \} (写真2), JEOL JMS-T100LC \{エレクト ロスプレーイオン化 (electrospray ionization; ESI), 大気圧 化学イオン化 (atmospheric pressure chemical ionization; APCI) \} (写真 4), Bruker Daltonics Autoflex2 \{マトリックス 支援レーザー脱離イオン化 (matrix-assisted laser desorption/ ionization; MALDI)\} (写真 5), JEOL JMS-Q1000TD (direct analysis in real time; DART) (写真6), JEOL JMS-S3000 （MALDI）(写真7）の5台です. Autoflex2 と JMS-Q1000TD は利用開放しており, 講習を受ければ学内外の方々にもご 利用いただけます。

本研究領域の質量分析装置は有機合成系の研究室が主に使っており，核磁気共鳴（Nuclear magnetic resonance; NMR） 装置で構造を確認して，質量分析装置やX線構造解析装置，元素分析装置で構造決定という流れが多いです。そのため， 未知物を測定することはあまりなく，予想構造を見て，適切なイオン化法を選択して測定します。上記5台の装置で EI, CI, FAB, ESI, APCI, MALDI, DARTの7種のイオン化法で測定することができます.

最近の仕事はJMS-S3000を用いて，精密質量測定を行うことが多くなってきています．JMS-S3000はMALDI法でイオ ン化したイオンをSpiral-TOF（spiral time-of-flight）質量分離部へ導入し，精密質量を測定することが可能な装置です．本 研究領域でよく測定する有機合成系の分子も壊れることなく $10 \mathrm{kDa}$ 程度の分子でも同位体ピークが分離し，きれいに測 定することができます。測定例としてデンドリマー（図1）のデータ（図2）を紹介します。こちらはマトリックスDCTB (trans-2-[3-(4-tert-Butylphenyl)-2-methyl-2-propenylidene] malononitrile) を用い，カチオン化剂としてTFA-Ag（trifluoroacetic acid-Ag）を用いました。 


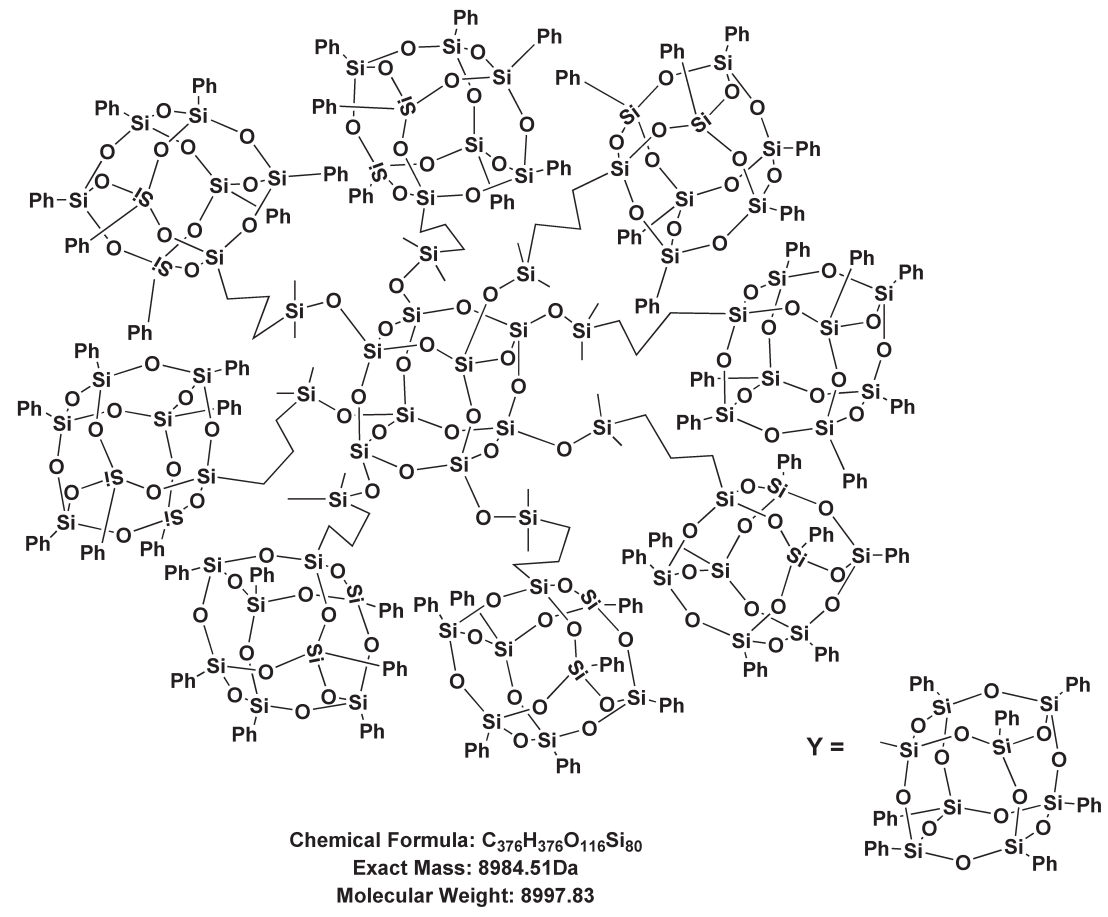

図 1. デンドリマーPhStarPOSS の構造式.

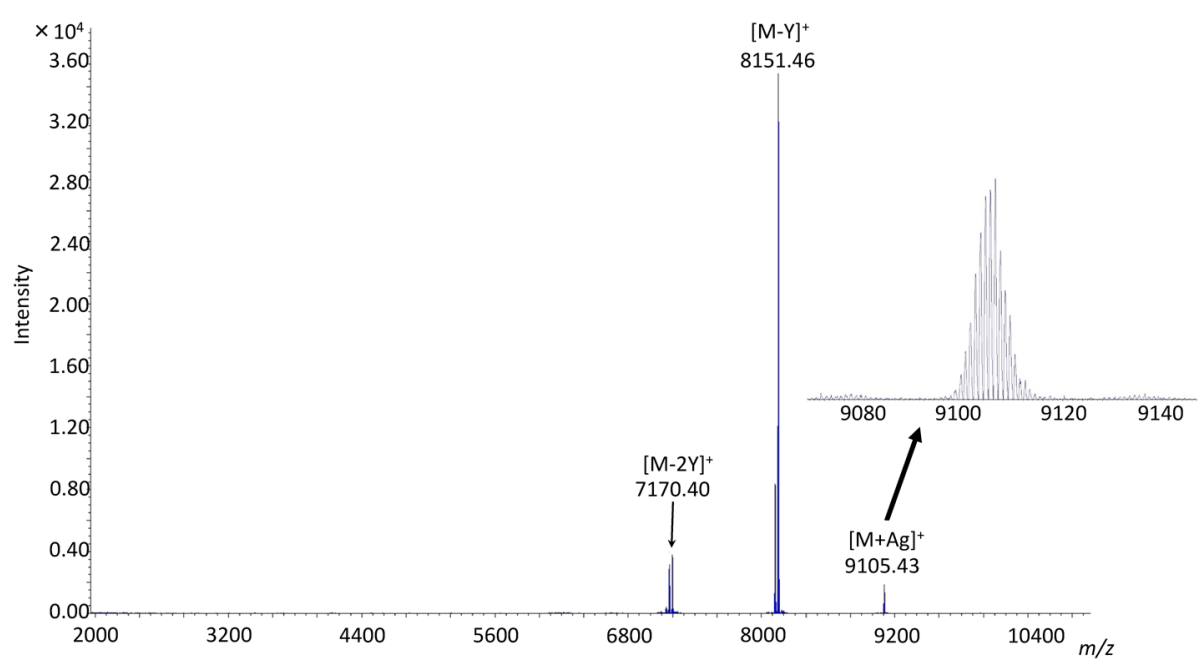

図2.PhStarPOSSの MALDI-Spiral-TOFマススペクトル.

\section{5. 最後に}

私は,この質量分析室紹介シリーズの先に発表をされていた大阪大学基礎工学部三宅里佳氏に後押しされ，第33回 BMS コンファレンスにて初めて託児を利用させていただきました。その後, 実行委員会の先生方のご尽力により質量分析 総合討論会でも託児が開設されるようになり，そちらを利用させていただきながら，現在に至っています，当初は，皆様 からの好意に甘えるばかりで，情報ももらう一方で（今でも…) 申し訳ない気持ちでいたのですが，そのおかげでたくさ ん勉強をさせていただき，仲間もたくさん増え，このような機会まで与えてもらえました．

今後も, 子育てや介護をしながらお仕事をされる方がどんどん増えてくると思いますが, このような制度が充実し, 続 いていってほしいと切に願っております. 